\title{
Laboratory culture of marine planktonic oligotrichs (Ciliophora, Oligotrichida)
}

\author{
Dian J. Gifford \\ Department of Oceanography, Dalhousie University, Halifax, Nova Scotia B3H 4J1, Canada
}

\begin{abstract}
Marine planktonic oligotrichs of the genera Strombidium and Strombidinopsis were collected from the Northwest Arm of Halifax Harbour, isolated, and maintained in monospecific batch culture for periods ranging from weeks to 10 mo. Successful laboratory culture was a function of appropriate phytoplankton food and the chemical composition of the oligotrich culture medium. Maximal reproductive rates, as doublings per day, were obtained when the oligotrichs were fed 2 dinoflagellate strains, Heterocapsa triquetra and Scrippsiella trochoidea, and when the organisms were grown in seawater medium containing $10^{-8}$ to $10^{-6} \mathrm{M} \mathrm{Na}_{2}$-EDTA and trace metals. Oligotrich cultures fed diatoms of the spinose genus Thalassiosira exhibited poor growth, regardless of the culture medium used. Losses of oligotrichs from field collections due to handling ranged from 20 to $60 \%$, depending on the methods of collection and concentration used.
\end{abstract}

\section{INTRODUCTION}

Because of their small size and rapid metabolic rates, the compartment of the plankton defined operationally as the microzooplankton (i.e. organisms $<200 \mu \mathrm{m}$ ) is postulated to play a significant role in pelagic food webs, forming a trophic link between small phytoplankton and macrozooplankton (e.g. Beers et al. 1971, Smetaček 1981, Azam et al. 1983). Within the microzooplankton, ciliates are numerically abundant and contain 2 related groups, the Oligotrichina (oligotrichs) and the Tintinnina (tintinnids), which are ubiquitous in neritic and oceanic waters. During the past 2 decades, several tintinnid species - primarily members of the genera Tintinnopsis, Favella and Helicostomella - have been isolated and maintained in the laboratory (Gold 1968, 1969, 1970, 1971, Johansen 1976, LavalPeuto 1977, Heinbokel 1978a, Paranjape 1980 , Stoecker et al. 1981).

Although they are more abundant than tintinnids in cases where both groups have been enumerated (Beers \& Stewart 1967, 1969a, b, 1970, 1971, Beers et al. 1971, 1975, Johansen 1976, Rassoulzadegan \& Gostan 1976, Smetaček 1981), planktonic oligotrichs have rarely been cultured. The freshwater species, Strobilidium gyrans (Stokes 1887) (Grim \& Halcrow 1979), and the interstitial species, Strombidium sulcatum Claparède et Lachmann 1859 (Gold 1982, Martinez 1983), are exceptions. The culture of marine planktonic oligo- trichs has not been reported previously. Their fragility and the difficulties of examination, preservation, and enumeration have been noted by workers studying their taxonomy (e.g. Fauré-Fremiet 1924, Kahl 1932) and their patterns of distribution and abundance (e.g. Beers et al. 1971, 1975, Smetaček 1981).

Laboratory culture of planktonic oligotrichs is a prerequisite for making measurements of physiological rates under controlled conditions. Such rate functions for the microzooplankton are not well known; they are of importance in the design of realistic models of pelagic food webs and in understanding the role of these small organisms in marine ecosystems.

\section{METHODS}

Collection. Seawater was collected from a shore station on the Northwest Arm of Halifax Harbour $(\mathrm{z}=1 \mathrm{~m})$ using either a weighted bucket or a $20 \mu \mathrm{m}$ mesh plankton net towed slowly by hand from shore. The water depth at this location is ca $2.5 \mathrm{~m}$ at high tide. The water temperature was recorded.

Concentration. Prior to isolating monospecific oligotrich cultures, the microzooplankton field assemblage was concentrated to facilitate handling. Four methods were compared:

(1) Size fractionation. The collected seawater was poured through submerged Nitex meshes. Porosities of 
202,100 and $53 \mu m$ were used, according to the design of the experiment. Samples of seawater taken before and after passage through the mesh were preserved in acid Lugols solution (Throndsen 1978). Tintinnid and oligotrich ciliates were enumerated using a dissecting microscope.

(2) Reverse filtration. Microzooplankton were concentrated with a reverse filtration apparatus adapted from the design of Dodson \& Thomas (1964). The flow rate through the apparatus was arranged so that $4 \mathrm{l}$ of seawater were concentrated to a volume of 100 to $200 \mathrm{ml}$ in ca $20 \mathrm{~min}$. Samples of seawater were collected before and after reverse filtration against a $10 \mu m$ Nitex mesh and preserved with acid Lugols solution. Tintinnids and oligotrichs were enumerated using a dissecting microscope. When phytoplankton clogged the mesh, the flow was stopped and the mesh was replaced.

(3) Pipetting. Samples of seawater were placed in borosilicate crystallization dishes (volume $=$ ca $50 \mathrm{ml}$ ) and stored in an incubator at the appropriate environmental temperature. Individual oligotrichs were picked with a drawn pipette under a dissecting microscope and transferred to tissue culture well plates (Falcon Company, Oxnard, California). The transfer efficiency of the pipetting method was assessed by counting oligotrichs as they were picked up with the pipette, preserving the contents of the pipette with acid Lugols solution, and counting the preserved oligotrichs: transfer efficiency $=$ (number of oligotrichs recovered/number of oligotrichs picked) x 100 .

(4) Enrichment. Samples of seawater containing microzooplankton, treated by one or a combination of the methods described above, were placed in borosilicate glass beakers (volume $=100$ to $400 \mathrm{ml}$ ). Log-phase phytoplankton cells were added to a food level of 100 to $200 \mu \mathrm{g} \mathrm{C} \mathrm{I}{ }^{-1}$, calculated from Strathmann (1967). The beakers were covered with watchglasses and incubated at ambient temperature for 24 to $48 \mathrm{~h}$. Oligotrich species which exhibited positive growth were then sorted with a drawn pipette.

Phytoplankton culture. Ten algal strains, selected to cover a range of sizes and types of phytoplankton cells, were used as food for oligotrich cultures (Table 1). The phytoplankton cultures were maintained by the methods of Guillard (1972) in borosilicate flasks in sterile $\mathrm{f} / 2$ medium (Guillard \& Ryther 1962) or in polycarbonate flasks in sterile $\mathrm{f} / 2$ medium without $\mathrm{SiO}_{3}$. Log-phase phytoplankton cultures were adapted to the temperature regime of each oligotrich culture experiment for 24 to $48 \mathrm{~h}$ prior to the beginning of an experiment.

Oligotrich culture. Regardless of the means by which they were collected and concentrated, oligotrich cultures were subsequently isolated by the procedures described below.

(1) Glassware and culture vessels. Glassware and culture vessels were cleaned with laboratory deter-

Table 1. Phytoplankton species used as food items for oligotrich cultures. NEPCC $=$ Northeast Pacific Culture Collection; WHOI $=$ Woods Hole Oceanographic Institution; NRC = National Research Council (Canada), Atlantic Regional Laboratory; UTEX = University of Texas Culture Collection. Dimensions are approximate and were measured microscopically using an ocular micrometer

\begin{tabular}{|c|c|c|c|}
\hline Species & Strain & Source & $\begin{array}{l}\text { Dimensions } \\
(\mathrm{L} \times \mathrm{W} ; \mu \mathrm{m})\end{array}$ \\
\hline $\begin{array}{l}\text { Cryptophyceae } \\
\text { Chroomonas salina (Wislouch) Butcher }\end{array}$ & $3 C$ & WHOI & $14 \times 10$ \\
\hline $\begin{array}{l}\text { Dinophyceae } \\
\text { - Heterocapsa triquetra Stein } \\
\text { - Scrippsiella trochoidea (Stein) Loeblich III }\end{array}$ & $\begin{array}{l}\text { HT }-984 \\
\text { D-15 }\end{array}$ & $\begin{array}{l}\text { WHOI } \\
\text { NEPCC }\end{array}$ & $\begin{array}{l}26 \times 16 \\
15 \times 15\end{array}$ \\
\hline $\begin{array}{l}\text { Haptophyceae } \\
\text { Isochrysis galbana Parke } \\
\text { Syracosphaera carterae }\end{array}$ & $\begin{array}{l}\mathrm{H}-2 \\
\text { SYR }\end{array}$ & $\begin{array}{l}\text { NEPCC } \\
\text { NRC }\end{array}$ & $\begin{array}{c}6 \times 6 \\
12 \times 12\end{array}$ \\
\hline $\begin{array}{l}\text { Bacillariophyceae } \\
\text { Thalassiosira weissflogii (Grunow) Fryxell et Hasle } \\
\text { Thalassiosira pseudonana (Hustedt) Hasle et Heimdal }\end{array}$ & $\begin{array}{l}\text { Actin } \\
13-1\end{array}$ & $\begin{array}{l}\text { WHOI } \\
\text { WHOI }\end{array}$ & $\begin{aligned} 18 & \times 12 \\
4 & \times 4\end{aligned}$ \\
\hline $\begin{array}{l}\text { Prasinophyceae } \\
\quad \text { Tetraselmis chuii Butcher } \\
\cdot \text { Micromonas pusilla (Butcher) Manton et Parke }\end{array}$ & $\begin{array}{l}232 \\
\text { P-29 }\end{array}$ & $\begin{array}{l}\text { UTEX } \\
\text { NEPCC }\end{array}$ & $\begin{array}{r}12 \times 8 \\
2 \times 1\end{array}$ \\
\hline $\begin{array}{l}\text { Chlorophyceae } \\
\text { Dunaliella tertiolecta Butcher } \\
\text { - Grown in medium } \mathrm{f} / 2-\mathrm{SiO}_{3} \text { in polycarbonate vessels }\end{array}$ & $C-1$ & NEPCC & $13 \times 10$ \\
\hline
\end{tabular}


gent, soaked in $10 \% \mathrm{HCl}$, and rinsed with distilled water. To remove trace contaminants, all vessels were autoclaved with distilled water in them and the water discarded.

(2) Culture media. Seawater to make oligotrich culture media was obtained from the Dalhousie University Aquatron system (Balch et al. 1978), which pumps water from a depth of $15 \mathrm{~m}$ from the Northwest Arm of Halifax Harbour. The seawater was passed through 3.0 and $0.3 \mu \mathrm{m}$ Gelman cartridge filters (Gelman Sciences Inc., Ann Arbor, Michigan) attached to the seawater line. Following unsuccessful preliminary attempts to culture oligotrichs in filtered seawater, 2 chelated culture media were used: the first consisted of filtered seawater with $\mathrm{Na}_{2}$-EDTA added; the second, of filtered seawater with $\mathrm{Na}_{2}$-EDTA and trace metals added. The stock solutions of $\mathrm{Na}_{2}$-EDTA and $\mathrm{Na}_{2}$-EDTA plus trace metals were made according to the recipe for phytoplankton f/2 medium (Guillard \& Ryther 1962). In oligotrich culture experiments, media treatments consisted of 5 concentrations of the metal chelator, ranging from $10^{-9}$ to $10^{-5} \mathrm{M}$. In media containing both $\mathrm{Na}_{2}$ EDTA and trace metals, the proportion of chelator to metals was the same for each dilution of $\mathrm{Na}_{2}$-EDTA, i.e. the concentration of trace metals was adjusted by dilution in keeping with the concentration of the chelator. The media were autoclaved in Teflon bottles, then stored for at least $48 \mathrm{~h}$ before the beginning of an experiment to avoid short-term changes in chelatormetal equilibria (Anderson \& Morel 1978).

(3) Physical factors. Oligotrichs were kept in incubators generally at temperatures as close as possible to that of the environment from which they were collected. Oligotrichs were grown under the same light regime as the phytoplankton stock cultures: a 14:10 light:dark cycle and illumination of ca $100 \mu \mathrm{E} \mathrm{m} \mathrm{m}^{-2} \mathrm{~s}^{-1}$.

(4) Sterility. Although the phytoplankton cultures used as food for the oligotrich cultures were maintained under sterile conditions and the oligotrich culture media were autoclaved, oligotrichs were not grown under axenic conditions. Preliminary attempts to add antibiotics to the media resulted in death of oligotrichs. Fenchel (1980) has suggested that the feeding apparatus of the Oligotrichina is not structured for efficient capture of bacteria-sized particles at the concentrations in which such particles typically occur in pelagic ecosystems. While it has been demonstrated that Strombidium sulcatum is capable of consuming bacteria and reproducing successfully on an exclusively bacterial diet (Gold 1982, Martinez 1983), these studies do not cite the levels of bacteria used as food. Bacterial densities must have been high relative to natural levels to support the oligotrich growth rates reported by these authors. In my study, bacterial overgrowth of oligotrich cultures was not observed, and bacteria may be considered a supplement to, but not the principle component of, the oligotrichs diet in culture.

(5) Taxonomic identification. A taxonomic compendium of the suborder Oligotrichina does not exist; the difficulties involved in identifying oligotrichs to the species level have been noted by Fenchel (1968). Although the oligotrich strains isolated from the Northwest Arm of Halifax Harbour resemble species described by Lohmann (1908), Fauré-Fremiet (1924), and Kahl (1932) morphologically, their cell dimensions differ from those described by these authors. Hence, the organisms discussed below have been identified to genus and given a strain designation. On the basis of cell dimensions, it is probable that strains STR-01 and STR-02 were the same species (Table 2).

(6) Isolation procedure. Culture experiments were done in Falcon multiwell tissue culture plates (well volume $=2 \mathrm{ml}$ ) arranged in a factorial design with 5 media treatments of $10^{-9}$ to $10^{-5} \mathrm{M} \mathrm{Na}_{2}$-EDTA and 3 to 6 different unialgal food treatments of 5 replicates each. The food items were taken from log-phase phytoplankton cultures diluted in oligotrich culture media treatments to a concentration of 100 to $200 \mu \mathrm{g} \mathrm{C}^{-1}$ calculated following Strathmann (1967). Control treatments consisted of oligotrich culture media without phytoplankton. Oligotrichs were sorted by size and swimming motion (Dale \& Burkill 1982); 5 to 20 individuals of each type were placed in each well. The well plates were covered and incubated for 24 to $72 \mathrm{~h}$, then the numbers of oligotrichs in each well were counted under a dissecting microscope. Oligotrichs from treatments resulting in positive population growth were transferred to a larger volume of medium containing the same phytoplankton food and incubated.

The specific rate of oligotrich population growth, $\mu$, expressed as doublings day ${ }^{-1}$, was used to quantify the relative success of each culture treatment:

$$
\mu=(1 / T \log 2)\left(\log N_{t}-\log N_{0}\right) 24
$$

where $T=$ incubation time in hours; $N_{0}$ and $N_{t}=$ number of oligotrichs at the beginning and end of each experiment.

Culture maintenance. Because of the nature of the isolation procedure, the oligotrich cultures were not monoclonal isolates. During the early stages of isolation, the cultures were examined frequently under the dissecting microscope to ensure that a single oligotrich type had been isolated. In the rare instances when individuals other than those desired were present, they were removed with a drawn pipette and discarded. Preserved subsamples of each isolate were examined under a compound microscope. Oligotrich cell dimensions were measured using an ocular micrometer. 
Table 2. Oligotrich strains isolated from the Northwest Arm of Halifax Harbour. Taxonomic identifications to genus and, where possible, species type were determined from Kahl (1932) and Frauré-Fremiet (1924). Dimensions were measured on preserved whole-mounted specimens using an ocular micrometer. $\mathrm{L}=$ length $(\mu \mathrm{m})$; $\mathrm{OD}=$ oral diameter $(\mu \mathrm{m})$. Reason ended: $1=$ culture died; 2 incubator failure; $3=$ terminated by choice

\begin{tabular}{|c|c|c|c|c|c|c|c|c|}
\hline \multirow{2}{*}{$\begin{array}{l}\text { Oligotrich } \\
\text { strain }\end{array}$} & \multirow{2}{*}{$\begin{array}{c}\text { Taxonomic } \\
\text { identification }\end{array}$} & \multicolumn{2}{|c|}{ Dimensions } & \multirow{2}{*}{$\begin{array}{l}\text { Date } \\
\text { collected }\end{array}$} & \multirow{2}{*}{$\begin{array}{c}\text { Water } \\
\text { temperature } \\
\left({ }^{\circ} \mathrm{C}\right)\end{array}$} & \multirow{2}{*}{$\begin{array}{c}\text { Incubator } \\
\text { temperature } \\
\left({ }^{\circ} \mathrm{C}\right)\end{array}$} & \multirow{2}{*}{$\begin{array}{l}\text { Date } \\
\text { ended }\end{array}$} & \multirow{2}{*}{$\begin{array}{l}\text { Reason } \\
\text { ended }\end{array}$} \\
\hline & & L & OD & & & & & \\
\hline STR-01 & Strombidium sp. & 35 & 45 & 10 Aug 81 & 17.0 & 17.0 & 15 Aug 81 & 1 \\
\hline STR-02 & Strombidium sp. & 35 & 45 & 31 Aug 81 & 17.5 & 17.0 & 8 Sep 81 & 1 \\
\hline STR.03 & Strombidium sp. & 50 & 66 & 21 Sep 81 & 18.0 & 17.0 & 15 Oct 81 & 1 \\
\hline STR-04 & Strombidium sp. & 20 & 20 & 25 Sep 81 & 17.5 & 17.0 & 9 Dec 81 & 1 \\
\hline STR-05 & Strombidium sp. & 60 & 30 & 12 Oct 81 & 11.5 & 11.5 & 1 Feb 82 & 1 \\
\hline STR-06 & Strombidium sp. & 45 & 32 & 20 Oct 81 & 12.0 & 11.5 & 11 Jan 82 & 1 \\
\hline STR-07 & Strombidium sp. & 70 & 45 & $10 \mathrm{Dec} 81$ & 4.5 & 10.5 & 16 Feb 82 & 1 \\
\hline STR-AC & $\begin{array}{l}\text { Strombidinopsis } \\
\text { cf. acuminatum }\end{array}$ & $150-200$ & 65 & $14 \operatorname{Jan} 82$ & 4.0 & 15.0 & 4 Oct 82 & 1 \\
\hline STR-08 & Strombidium sp. & 54 & 32 & 1 Feb 82 & 2.0 & 4.5 & 3 Apr 82 & 1 \\
\hline STR-09 & Strombidium sp. & 25 & 25 & 16 Feb 82 & 2.5 & 4.5 & 28 Feb 82 & 1 \\
\hline STR-10 & Strombidium sp. & 30 & 50 & 2 Apr 82 & 4.0 & 6.0 & 28 Jun 82 & 1 \\
\hline STR-11 & Strombidium sp. & 45 & 30 & 19 Aрr 82 & 4.5 & 9.5 & $28 \mathrm{Jun} 82$ & 1 \\
\hline STR-12 & Strombidium sp. & 45 & 25 & 4 May 82 & 5.5 & 5.5 & 26 Sep 82 & 2 \\
\hline STR-13 & Strombidium sp. & 60 & 28 & 4 May 82 & 5.5 & 5.5 & 26 Sep 82 & 2 \\
\hline STR-14 & Strombidium sp. & 40 & 35 & 15 May 82 & 6.5 & 6.0 & 29 Jul 82 & 1 \\
\hline STR-15 & Strombidium sp. & 56 & 32 & 28 Jun 82 & 9.5 & 10.0 & $15 \mathrm{Jul} 82$ & 1 \\
\hline STR-16 & Strombidium sp. & 72 & 30 & 29 Sep 82 & 17.5 & 16.0 & 4 Oct 82 & 1 \\
\hline STRA-01 & Strombidium sp. & 50 & 35 & 2 oct 82 & 12.0 & 10.0 & 26 Jul 83 & 3 \\
\hline STRA-02 & Strombidium sp. & 25 & 20 & $21 \mathrm{Jan} 83$ & 1.5 & 4.5 & $26 \mathrm{Jul} 83$ & 3 \\
\hline STRA-03 & Strombidium sp. & 50 & 35 & 9 Feb 83 & 1.0 & 4.5 & 26 Jul 83 & 3 \\
\hline STRA-04 & Strombidium sp. & 35 & 30 & 25 Apr 83 & 3.0 & 4.5 & $26 \mathrm{Jul} 83$ & 3 \\
\hline
\end{tabular}

Although length and body volume were variable within each strain, oral diameter was constant.

The oligotrich cultures were handled and disturbed as little as possible. Cultures were examined under the dissecting microscope and food was added as necessary, typically at 4 to $7 \mathrm{~d}$ intervals. Cultures were maintained in the medium and fed a mixture of the 2 phytoplankton strains which resulted in maximum growth rates during the isolation procedure. Debris was removed from the bottom of the culture vessels and from the surface of the medium with a Pasteur pipette, as necessary. To transfer cultures, a portion of the culture volume was poured gently into another vessel, and both vessels were brought to full volume by addition of medium. Subsamples of successful cultures were collected on a weekly basis and the ciliates enumerated.

\section{RESULTS}

\section{Collection methods}

The results of collection by buckets and nets are compared in Table 3. Because the 2 methods did not sample the same volume of water, the ratio of the mean number of tintinnids to the mean number of oligotrichs was calculated to compare them. Although there were no differences in the relative abundances of tintinnids collected by the 2 methods, use of a $20 \mu \mathrm{m}$ mesh net resulted in losses of 33 to $50 \%$ of the oligotrichs.

\section{Concentration methods}

(1) Size fractionation. Passage through mesh of various sizes significantly reduced the numerical abundances of oligotrichs by 23 to $56 \%$, with greater losses occurring after passage through the smaller meshes. There was no significant change in tintinnid numbers (t-test for small samples; $p \leq 0.05$ ) (Table 4). Microscopic examination revealed that macrozooplankton and large phytoplankton were retained on the meshes; oligotrichs were not retained and were presumably destroyed by abrasion.

(2) Reverse filtration. Reverse filtration against a $10 \mu \mathrm{m}$ mesh did not significantly alter the numbers of tintinnids enumerated. Loss of oligotrichs from the same samples ranged from 75 to $77 \%$ (t-test for small samples; $p \leq 0.05$ ) (Table 5).

(3) Pipetting. The transfer efficiencies of picking individual oligotrichs with a drawn pipette ranged from 93 to $100 \%$. For unconcentrated samples, this Inethod was labour intensive. 
(4) Enrichment. Enrichment of collected assemblages of microzooplankton with cultured phytoplankton was the most satisfactory method for obtaining dense concentrations of oligotrichs: (a) it was not labour intensive; and (b) it involved minimal handling of the collected material.

Table 3. Collection methods. Effect of collection method on numerical abundance of planktonic oligotrichs and tintinnids. Table entries are mean numbers $/ 20 \mathrm{ml}$ obtained by enumeration of 3 replicate samples under the dissecting microscope. Values in parentheses are standard deviations. Because the 2 methods did not sample the same volume of water, the ratio of mean number of tintinnids to mean number of oligotrichs was calculated in order to compare them

\begin{tabular}{|c|c|c|c|c|}
\hline Date & $\begin{array}{l}\text { Collection } \\
\text { method }\end{array}$ & $\begin{array}{c}(\mathrm{A}) \\
\text { Tintinnids } \\
(20 \mathrm{ml})^{-1}\end{array}$ & $\begin{array}{c}\text { (B) } \\
\text { Oligotrichs } \\
(20 \mathrm{ml})^{-1}\end{array}$ & $\begin{array}{l}\text { Ratio } \\
\text { (A/B) }\end{array}$ \\
\hline \multirow[t]{2}{*}{6 Apr 81} & Bucket & $\begin{array}{l}14.00 \\
(4.35)\end{array}$ & $\begin{array}{l}35.33 \\
(8.02)\end{array}$ & .4 \\
\hline & Net & $\begin{array}{l}14.33 \\
(5.51)\end{array}$ & $\begin{array}{l}18.00 \\
(1.00)\end{array}$ & .8 \\
\hline \multirow[t]{2}{*}{10 Apr 81} & Bucket & $\begin{array}{l}19.00 \\
(4.58)\end{array}$ & $\begin{array}{l}47.56 \\
(8.02)\end{array}$ & .4 \\
\hline & Net & $\begin{array}{l}22.67 \\
(5.51)\end{array}$ & $\begin{array}{l}22.00 \\
(6.00)\end{array}$ & 1.0 \\
\hline \multirow[t]{2}{*}{11 Apr 81} & Bucket & $\begin{array}{l}17.67 \\
(5.51)\end{array}$ & $\begin{array}{l}44.00 \\
(5.57)\end{array}$ & .4 \\
\hline & Net & $\begin{array}{l}19.67 \\
(5.13)\end{array}$ & $\begin{array}{c}15.67 \\
(4.62)\end{array}$ & 1.3 \\
\hline
\end{tabular}

\section{Isolation procedure}

Twenty-one monospecific strains of planktonic oligotrichs were isolated from the Northwest Arm of Halifax Harbour during 1981-1983 (Table 2). Examples of detailed short-term reproductive rates are given in Fig. 1 to 3. Three oligotrich strains (STR-AC; STRA$14 ;$ and STRA-02) have been selected as examples. The other 18 strains exhibited similar patterns, yielding 4 general results: (1) in control treatments with no food present, reproductive rates were negative; (2) reproductive rates were positive in the presence of certain food items; (3) reproductive rates were maximal with chelator concentrations of $10^{-8}$ to $10^{-6} \mathrm{M}$ and (4) where reproductive rates were positive, they were higher in the presence of trace metals. The magnitude of the reproductive rates attained in successful treatments, a maximum of ca 1 doubling $\mathrm{d}^{-1}$, is similar to that observed for tintinnids in laboratory culture (e.g. Gold 1968, Stoecker et al. 1983).
Table 4. Concentration methods. Examples of the effect of passage through mesh on numerical abundances of planktonic oligotrichs and tintinnids. Table entries are mean numbers $/ 20 \mathrm{ml}$, obtained by enumeration of 3 replicate subsamples under the dissecting microscope. Values in parentheses are standard deviations. \% loss is calculated by comparison of mean values after passage through mesh with those for no treatment. Pairs of values joined by vertical bars are significantly different (t-test for small samples; $p \leqslant .05$ )

\begin{tabular}{|c|c|c|c|c|}
\hline Date & $\begin{array}{l}\text { Treat- } \\
\text { ment }\end{array}$ & $\begin{array}{l}\text { Tintin- } \\
\text { nids } \\
(20 \mathrm{ml})^{-1}\end{array}$ & $\begin{array}{c}\text { Oligo } \\
\text { trichs } \\
(20 \mathrm{ml})^{-1}\end{array}$ & $\begin{array}{c}\% \text { Loss } \\
\text { of oligo } \\
\text { trichs }\end{array}$ \\
\hline \multirow[t]{3}{*}{12 Apr 81} & None & $\begin{array}{l}9.0 \\
(2.65)\end{array}$ & $\begin{array}{c}33.33 \\
(4.04)\end{array}$ & - \\
\hline & $102 \mu \mathrm{m}$ mesh & $\begin{array}{l}10.0 \\
(1.00)\end{array}$ & $\begin{array}{l}18.67 \\
(3.51)\end{array}$ & 56 \\
\hline & $202 \mu \mathrm{m}$ mesh & $\begin{array}{l}10.66 \\
(2.89)\end{array}$ & $\begin{array}{c}12.33 \\
(3.21)\end{array}$ & 37 \\
\hline \multirow[t]{4}{*}{17 Apr 81} & None & $\begin{array}{l}27.00 \\
(8.19)\end{array}$ & $\begin{array}{c}51.00 \\
(9.00)\end{array}$ & - \\
\hline & $53 \mu \mathrm{m}$ mesh & $\begin{array}{l}32.67 \\
(5.51)\end{array}$ & $\begin{array}{l}21.67 \\
(7.09)\end{array}$ & 42 \\
\hline & $102 \mu \mathrm{m}$ mesh & $\begin{array}{c}31.67 \\
(11.37)\end{array}$ & $\begin{array}{l}13.67 \\
(5.03)\end{array}$ & 26 \\
\hline & $202 \mu \mathrm{m}$ mesh & $\begin{array}{l}29.33 \\
(4.73)\end{array}$ & $\begin{array}{l}15.00 \\
(6.08)\end{array}$ & 29 \\
\hline \multirow[t]{4}{*}{13 Jul 81} & None & $\begin{array}{l}56.33 \\
(7.37)\end{array}$ & $\begin{array}{c}66.67 \\
(10.00)\end{array}$ & - \\
\hline & $53 \mu \mathrm{m}$ mesh & $\begin{array}{c}63.33 \\
(10.97)\end{array}$ & $\begin{array}{c}25.00 \\
(6.56)\end{array}$ & 38 \\
\hline & $102 \mu \mathrm{m}$ mesh & $\begin{array}{c}58.67 \\
(12.66)\end{array}$ & $\begin{array}{l}16.67 \\
(5.13)\end{array}$ & 25 \\
\hline & $202 \mu \mathrm{m}$ mesh & $\begin{array}{l}54.67 \\
(7.51)\end{array}$ & $\begin{array}{l}15.33 \\
(8.08)\end{array}$ & 23 \\
\hline
\end{tabular}

\section{Maintenance}

An example of the temporal history of one oligotrich culture, strain STR-AC, is given in Fig. 4. Standing stocks of oligotrichs, as numbers $\mathrm{ml}^{-1}$, fluctuated, tending to decrease after transfer and increase after feeding. The decrease in the standing stock of oligotrichs after transfer is attributed to handling. Pouring an oligotrich culture from one vessel to another, or gently adding medium to an existing culture, results in losses of oligotrichs (Gifford unpubl.). The data in Fig. 4 are cumulative and are corrected for transfer. Cultures tended to be food-limited prior to feeding. They were transferred when the standing stocks of oligotrichs reached ca 200 individuals $\mathrm{ml}^{-1}$, so that yields in excess of that level were not recorded at any one time. Oligotrichs in various stages of cell division were observed. With the exception of strain STR-AC, conju- 
Tabie 5. Concentration methods. Examples of the effect of reverse filtration on the numerical abundance of planktonic tintinnids and oligotrichs. Table entries are mean numbers liter $^{-1}$ obtained by enumeration of 3 replicate $10 \mathrm{ml}$ subsamples under the dissecting microscope. Values in parentheses are standard deviations. RF = Reverse Filtration. Pairs of values joined by vertical bars are significantly different ( $t$-test for small samples; $\mathrm{p} \leqslant .05$ )

\begin{tabular}{|c|c|c|c|}
\hline Treatment & $\begin{array}{l}\text { Tintinnids } \\
\text { liter }^{-1}\end{array}$ & $\begin{array}{l}\text { Oligotrichs } \\
\text { liter }^{-1}\end{array}$ & $\begin{array}{l}\% \text { Loss of } \\
\text { oligatrichs }\end{array}$ \\
\hline \multicolumn{4}{|c|}{ Date: 14 Apr 81} \\
\hline None & $\begin{array}{l}750.00 \\
(26.25)\end{array}$ & $\begin{array}{r}1680.00 \\
(60.96)\end{array}$ & \\
\hline RF & $\begin{array}{l}876.66 \\
(33.03)\end{array}$ & $\begin{array}{l}406.67 \\
(22.64)\end{array}$ & 76 \\
\hline \multicolumn{4}{|c|}{ Date: 17 Apr 81} \\
\hline None & $\begin{array}{c}383.33 \\
(8.28)\end{array}$ & $\begin{array}{l}823.33 \\
(11.68)\end{array}$ & \\
\hline RF & $\begin{array}{c}383.33 \\
(12.10)\end{array}$ & $\begin{array}{l}200.00 \\
(21.21)\end{array}$ & 76 \\
\hline \multicolumn{4}{|c|}{ Date: 17 Apr 81} \\
\hline None & $\begin{array}{c}413.33 \\
(7.58)\end{array}$ & $\begin{array}{l}953.33 \\
(14.21)\end{array}$ & \\
\hline RF & $\begin{array}{c}433.33 \\
(5.93)\end{array}$ & $\begin{array}{l}200.00 \\
(10.80)\end{array}$ & 79 \\
\hline
\end{tabular}

gation was not observed. Strains survived for periods ranging from a few weeks to nearly 1 yr (Table 2). In food depleted cultures, cannibalism was commonly observed.

\section{DISCUSSION}

Losses due to sampling and handling. The fragility of oligotrichs at all stages of the culture process, from collection, to concentration and isolation, has implications for studies of the distribution and abundance of these organisms in nature. The advantages of counting live organisms to obtain accurate abundance estimates of these forms has been emphasized by Sorokin (1977, 1981) and Dale \& Burkill (1982). Abundance estimates derived from samples which have been passed through, or collected upon, a plankton mesh must be viewed as conservative. Up to $60 \%$ of the oligotrichs sampled were lost, depending on how the organisms were collected and handled (Tables 3 to 5). The smaller mesh size $(10 \mu \mathrm{m})$ used for reverse filtration probably accounts for the greater losses of oligotrichs with this method. Additional losses occur due to fixation (Gifford unpubl.).

Specificity of phytoplankton food. Although the oligotrich strains isolated and maintained in this study exhibited positive growth rates when fed several strains of phytoplankton, growth was maximal on only

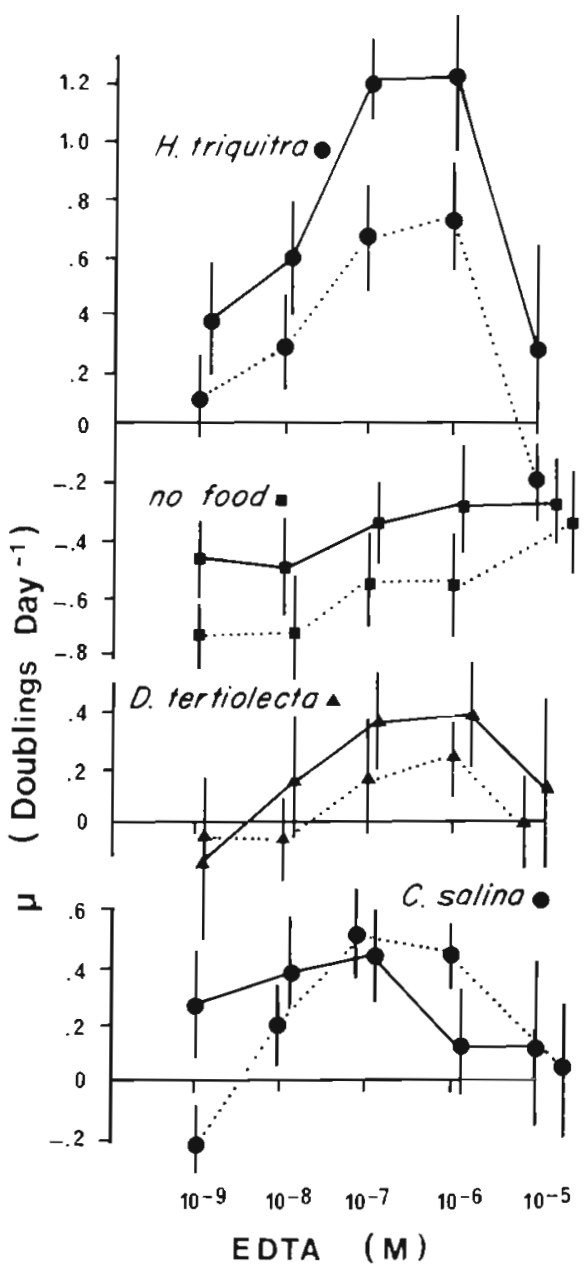

Fig. 1. Short-term reproductive rates, aligotrich strain STRAC given 3 phytoplankton food treatments and grown in filtered seawater with $\mathrm{Na}_{2}$-EDTA (broken lines) and $\mathrm{Na}_{2}$ EDTA + trace metals (solid lines) added at $15^{\circ} \mathrm{C}$. Points: means of 5 replicates \pm standard deviations; controls: oligotrichs in media treatments without food

1 or 2 of the food types offered to each culture. Two dinoflagellate species, Heterocapsa triquetra and Scrippsiella trochoidea, gave maximal oligotrich growth in 66 and $100 \%$ of the cases in which they were used. A cryptophyte, Chroomonas salina, provided maximal oligotrich growth in $35 \%$ of the cases in which it was used as a food item.

Because of the small number of phytoplankton strains tested, it is difficult to extract generalizations from the results. Those phytoplankton strains promoting maximal growth were motile cells. It has been reported that planktonic oligotrichs do not consume diatoms (Blackbourn 1976), although interstitial forms apparently do so (Fenchel 1968). Although the point has not been examined rigourously in the present study, in the 4 cases where diatoms were used as food (oligotrich strains STR-04; STR-06; STR-07; and STR08), growth rates were either slight or negative. This 


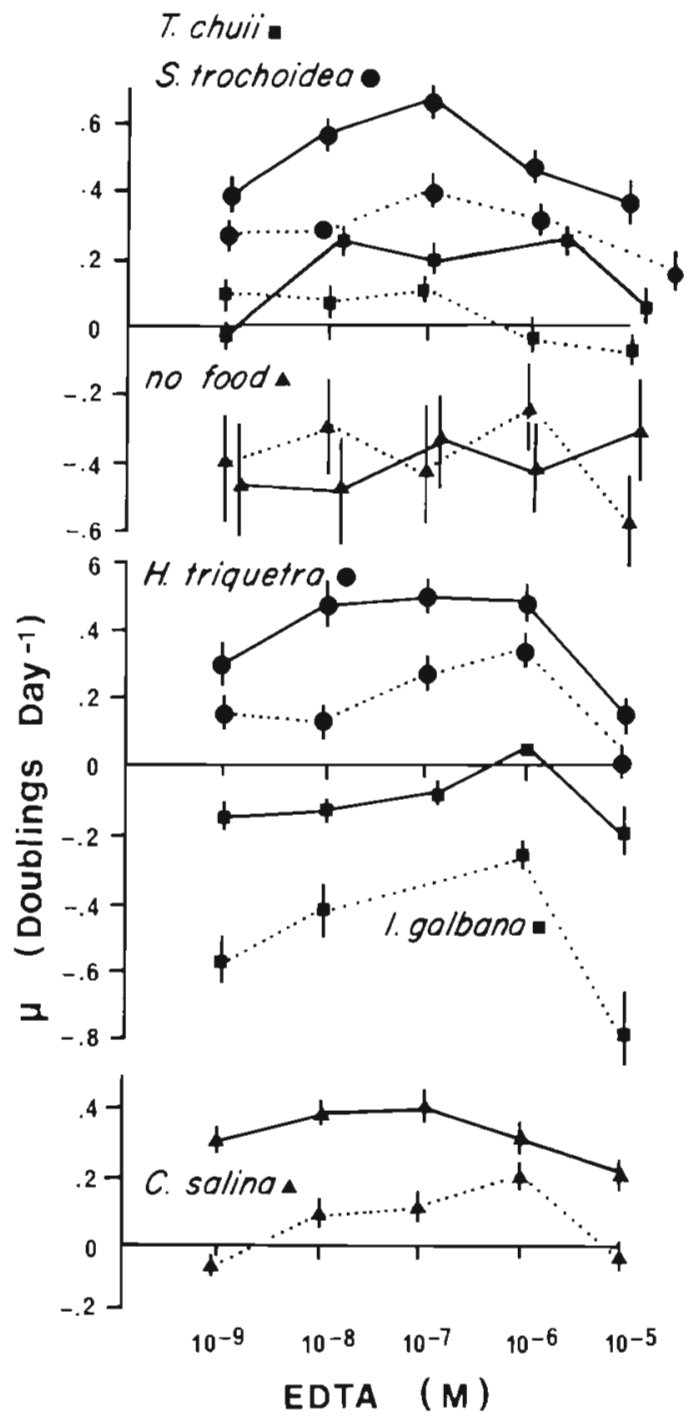

Fig. 2. Short-term reproductive rates, oligotrich strain STR-14 given 5 phytoplankton food treatments and grown in filtered seawater with $\mathrm{Na}_{2}$-EDTA (broken lines) and $\mathrm{Na}_{2}$-EDTA + trace metals (solid lines) added at $6{ }^{\circ} \mathrm{C}$. Points: means of 5 replicates \pm standard deviations; controls: oligotrichs in media treatments without food

may be a consequence of the presence of $\beta$-chitin filaments on the 2 Thalassiosira strains fed to the oligotrichs rather than a reflection of the nutritional adequacy of the diatoms. The $\beta$-chitin filaments confer a larger effective size on the diatom cells that possess them, rendering them more likely to be consumed by herbivorous copepods (Gifford et al. 1981) and less likely to be consumed by microzooplankton (Verity 1984). The diatoms consumed by the interstitial oligotrichs described by Fenchel (1968) were apparently pennate forms lacking spinose processes.

The 2 dinoflagellate strains promoting maximal oligotrich growth rates had larger cell diameters and volumes than most of the other phytoplankton cells

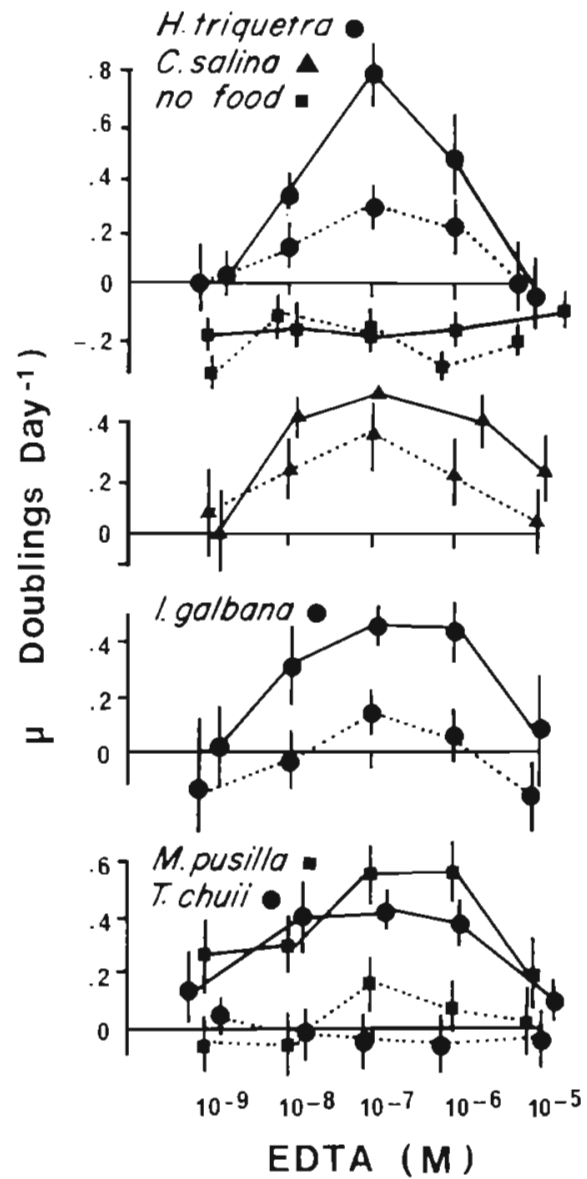

Fig. 3. Short-term reproductive rates, oligotrich strain STRA01 given 5 phytoplankton food treatments and grown in filtered seawater with $\mathrm{Na}_{2}$-EDTA (broken lines) and $\mathrm{Na}_{2}$ EDTA + trace metals (solid lines) added at $10^{\circ} \mathrm{C}$. Points: means of 5 replicates \pm standard deviations; controls: oligotrichs in media treatments without food

used as food (Table 1). The slope of the regression of the size of phytoplankton cells giving maximum oligotrich growth versus oligotrich oral diameter is not significantly different from zero $\left(\mathrm{r}^{2}=0.15\right.$; d.f. $=20$; $p \geqslant 0.05)$; oligotrichs of a range of oral diameters achieved maximal growth rates when fed the 2 dinoflagellate strains (Fig. 5). However, oligotrich growth rates were dependent on phytoplankton cell size $\left(r^{2}=0.34\right.$; d.f. $\left.=60 ; p \leq 0.05\right)$ (Fig. 6). Unlike tintinnids, in which rigidity of the lorica apparently limits the maximum size of food items ingested to approximately 45 to $50 \%$ of the oral lorica diameter (Spittler 1973, Blackbourn 1974, Heinbokel 1978b), oligotrichs are able to ingest food items as large as themselves: in food depleted cultures, they consume each other (Gifford unpubl.). It appears that the dinoflagellate cells which promoted maximal oligotrich growth rates may have been selected on the basis of their size, but not as a function of the oligotrichs' oral diameter. Although the question was not addressed explicitly, it is also 


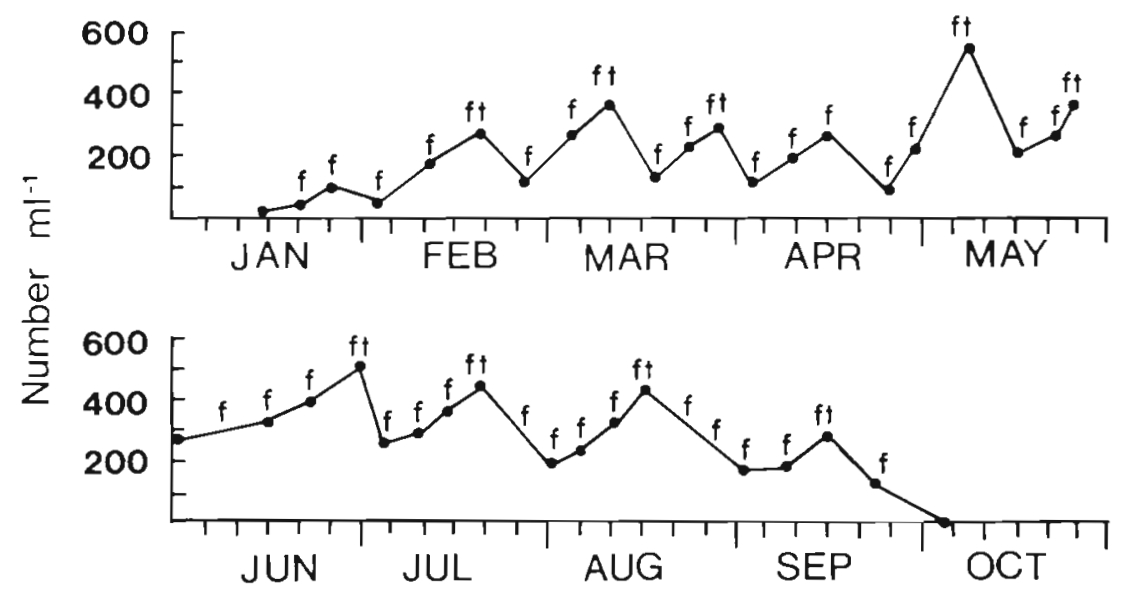

Fig. 4. Culture history of oligotrich strain STR-AC fed Heterocapsa triquetra and Chroomonas salina. Points: numbers per $\mathrm{ml}$ corrected for transfer $; \mathrm{f}=$ feeding; $\mathrm{t}=$ transfer

possible that the dinoflagellates were selected on the basis of factors other than size (e.g. motility, chemical composition), or that the oligotrichs were preconditioned to consume dinoflagellates in their natural milieu: oligotrichs frequently co-occur with large dinoflagellates in Halifax Harbour (Johansen 1976 , Gifford unpubl.) and elsewhere (Stoecker et al. 1984). One tintinnid, Favella sp., has also been reported to prefer dinoflagellate foods (Stoecker et al. 1981).

Chelation and trace metals. A concentration of chelator and trace metals in culture medium exists that promoted increased oligotrich growth rates, suggesting that the oligotrichs required some component of the trace metal mixture (Fig. 1 to 3 ). The culture exper- iments do not resolve which trace metals in the mixture affected the oligotrichs or how they did so. The effects may be direct or transmitted indirectly by means of metal-ligand effects on the oligotrichs' phytoplankton food: the oligotrichs may have higher grazing rates, and thus, higher reproductive rates, when fed phytoplankton cells growing at optimal chelator-trace metal levels. The effect of chelators exuded by the phytoplankton cells themselves (e.g. Trick et al. 1983) has not been examined, although it is possible that chelator release by phytoplankton cells may act either to enhance or depress oligotrich growth. Other workers have had success in culturing tintinnids in medium containing chelator and trace metals: Stoecker et al.

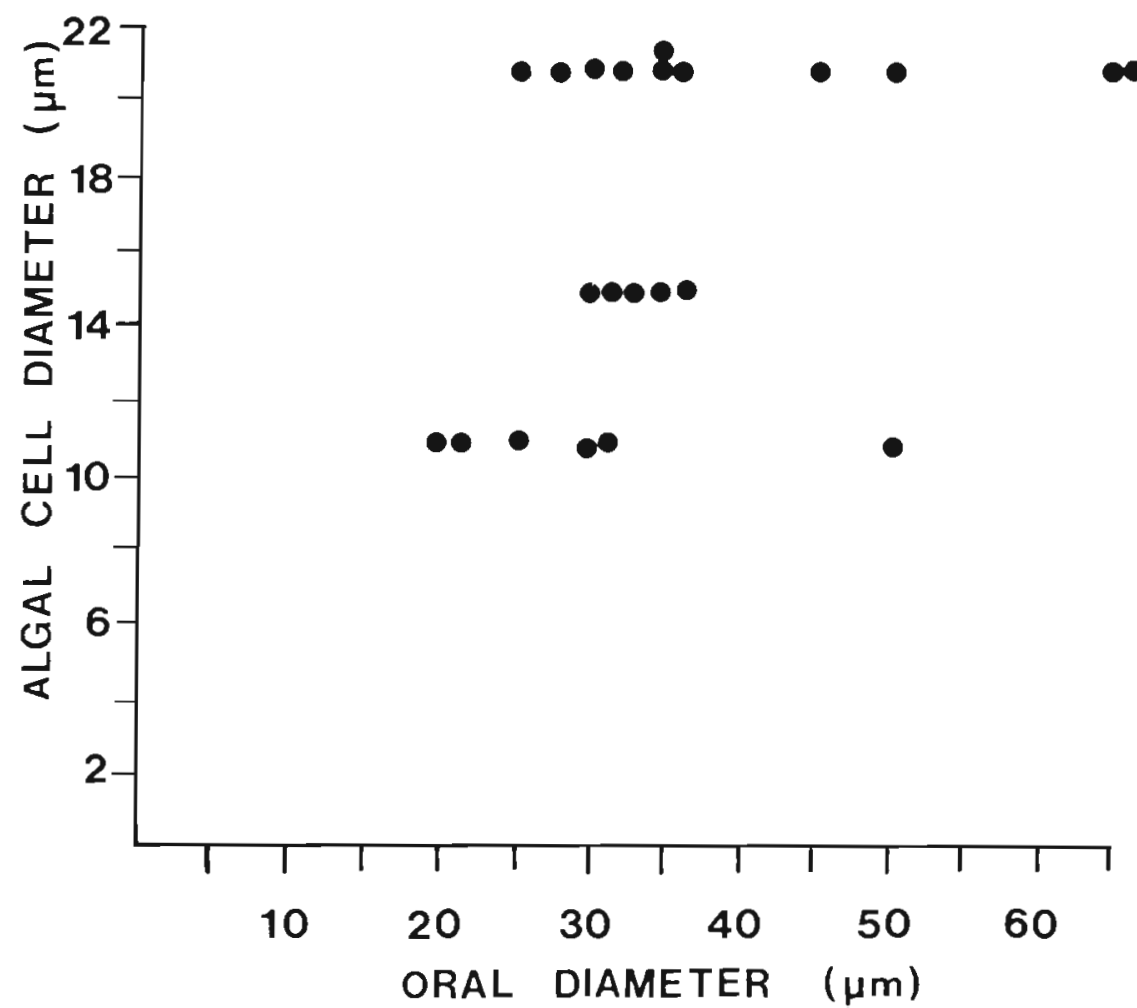

Fig. 5. Dependence of phytoplankton food items resulting in maximal reproductive rates on oligotrich oral diameter. Phytoplankton cell diameters were measured as in Table 1. Oligotrich oral diameters were measured as in Table 2. $\mathrm{I}^{2}=0.15 ; \mathrm{p} \geqslant 0.05$ 
Fig. 6. Dependence of oligotrich reproductive rates on phytoplankton cell size, as cell volume. Points: maximum observed oligotrich doublings per day for each food treatment in which positive growth occurred. Growth rates are normalized as $\% \mu_{\max }$ within each culture experiment in order to compare rates recorded at different temperatures. Phytoplankton cell volumes are calculated from cell linear dimensions and geometry (Table 1). Only data from experiments done in culture medium containing both $\mathrm{Na}_{2}$-EDTA and trace metals are included. Points marked with numerals indicate the number of points having the same value. $\mathrm{r}^{2}=0.34 ; \mathrm{p} \leqslant 0.05$

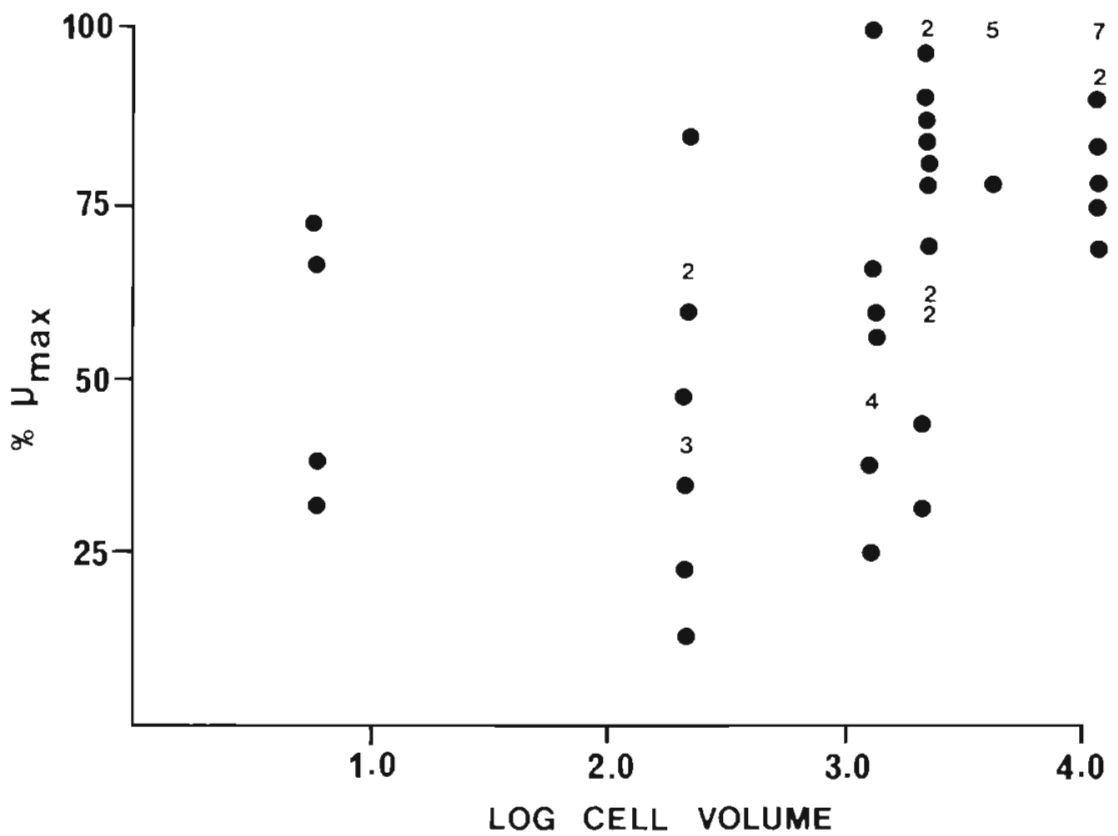

(1981) grew the tintinnid Favella sp. in seawater medium containing 1.2 to $6.0 \times 10^{-7} \mathrm{M} \mathrm{Na}_{2}$-EDTA plus iron; Gold's (1968) synthetic medium ' $D$ ' for tintinnids contains both $\mathrm{Na}_{2}$-EDTA and trace metals; and Verity (1984) cultivated tintinnids in $\mathrm{f} / 20$ medium (Guillard \& Ryther 1962) which also contains chelator and trace metals. These studies did not examine the effect of variable chelator or metal concentrations on tintinnid growth.

The curves of oligotrich reproductive rates as a function of chelator concentration (Fig. 1 to 3 ) are similar to models describing the effects of chelation and trace metals on phytoplankton growth (Jackson \& Morgan 1978, Huntsman \& Sunda 1980): in the presence of an optimum amount of chelator, toxic levels of metals are not attained and maximal growth occurs. At chelator concentrations below the optimum (here, $10^{-8}$ to $10^{-6}$ M), growth is reduced, perhaps due to metal toxicity. At chelator concentrations above the optimum, metals essential for nutrition are reduced to levels below those necessary for maximal growth.

In the small volumes of seawater medium used in the culture experiments, it is expected that reactions between components of the medium and the vessel walls will be enhanced (Lewin \& Chen 1973), so that the effects of chelation and trace metals per se on oligotrich growth in small culture volumes may have little bearing on processes occurring in the unbounded volumes of pelagic ecosystems. Therefore, extrapolation of the effects of trace metals and chelation in culture to field situations should be approached with caution.

Culture maintenance. Survival of the 21 oligotrich strains was variable. While some died in incubator malfunctions or were terminated deliberately, most cultures eventually went into an apparently spontaneous decline, ceased to reproduce, and died off. This sort of decline has also been observed in tintinnids (Gold 1970, Paranjape 1980); it is attributed to cessation of conjugation, the sexual mode of reproduction in which genetic recombination occurs by means of micronuclear exchange (Hiwatashi 1974). In the absence of conjugation, the laboratory strain eventually becomes less viable over time.

Applications. The impact of collection and concentration methods on oligotrichs is severe. The large losses due to sampling and handling suggest that estimates of oligotrich abundances in nature, and calculations of their trophic impact extrapolated from such estimates (e.g. Heinbokel \& Beers 1979, Landry \& Hassett 1982) must be viewed as conservative.

The value of developing reliable culture methods for microzooplankton organisms lies in making physiological measurements under controlled conditions, allowing rate functions to be attached to trophic links in models of pelagic food webs (Gold 1970, Sieburth 1982). To evaluate the physiological rate functions applied to trophic models of pelagic ecosystems, laboratory measurements made under optimal conditions may be compared to those obtained from field experiments which are done, by necessity, under less controlled conditions (e.g. Landry \& Hassett 1982). At present, such rate functions for the microzooplankton component of the plankton are not well known, and they are unknown for oligotrich ciliates.

The methods described here are devoted explicitly 
to the culture of marine planktonic oligotrichs. It is probable that they may be applied to other protozoans, as well as to delicate macrozooplankton organisms.

Acknowledgements. The research reported in this paper fulfills part of the requirements for the Ph. D. degree from Dalhousie University. The research was supported by grants from the Natural Sciences and Engineering Research Council of Canada to Carl M. Boyd. I was supported by a Dalhousie Graduate Fellowship. I am grateful for the enthusiasm of Diane K. Stoecker and the support and encouragement of Carl M. Boyd. I thank Kate Boyd for help in the laboratory and Suzanne Roy for tending the oligotrich cultures during my absences. Critical readings by Carl $\mathrm{M}$. Boyd, Peter H. Burkill, Robert J. Conover, Kenneth Gold, Eric L. Mills, Madhu Paranjape, Diane K. Stoecker, Peter G. Verity and two anonymous reviewers improved the manuscript.

\section{LITERATURE CITED}

Anderson, D. M., Morel, F. M. M. (1978). Copper sensitivity of Gonyaulax tamarensis. Limnol. Oceanogr. 23: 283-295

Azam, F., Fenchel, T., Field, J. G, Gray, J. S., Meyer-Reil, L. A., Thingstad, F. (1983). The ecological role of water column microbes in the sea. Mar. Ecol. Prog. Ser. 10: $257-263$

Balch, N., Boyd, C. M., Mullin, M. (1978). Large-scale tower tank systems. Rapp. P.-v. Réun. Cons. int. Explor. Mer 173: 13-21

Beers, J. R., Stewart, G. L. (1967). Microzooplankton in the euphotic zone at five locations across the California Current. J. Fish. Res. Bd Can. 24: 2053-2068

Beers, J. R. (1969a). The vertical distribution of microzooplankton and some ecological observations. J. Cons. int. Explor. Mer 33: 30-44

Beers, J. R. (1969b). Microzooplankton and its abundance relative to the larger zooplankton and other seston components. Mar. Biol. 4: 182-189

Beers, J. R. (1970). The ecology of the plankton off LaJolla, California in the period April-September, 1967. Part III. Numerical abundance and estimated biomass of microzooplankton. Bull. Scripps Inst. Oceanogr. 17: 67-87

Beers, J. R. (1971). Microzooplankters in the plankton communities of the upper waters of the eastern tropical Pacific. Deep Sea Res. 18: 861-883

Beers, J. R., Stevenson, M. R., Eppley, R. W., Brooks, E. R. (1971). Plankton populations and upwelling off the coast of Peru, June, 1969. Fish. Bull. U.S. 69: 859-876

Beers, J. R., Reid, F. M. H., Stewart, G. L. (1975). Microplankton of the North Pacific central gyre. Population structure and abundance, June, 1973. Int. Revue ges. Hydrobiol. 60 : $607-638$

Blackbourn, D. J. (1974). The feeding biology of tintinnid protozoa and other inshore microzooplankton. Ph. D. thesis, University of British Columbia, Vancouver

Dale, T., Burkill, P. H. (1982). 'Live-counting'-a quick and simple technique for enumeration pelagic ciliates. Annls Inst. océanogr., Paris 58: 267-276

Dodson, A. N., Thomas, W. H. (1964). Concentrating plankton in a gentle fashion. Limnol. Oceanogr. 9: 455-456

Fauré-Fremiet, E. (1924). Contribution à la connaissance des infusoires planctoniques. Bull. biol. Fr. Belg. 6 (Suppl.): $1-171$
Fenchel, T. (1968). The ecology of marine microbenthos II. The food of marine benthic ciliates. Ophelia 5: 73-121

Fenchel, T. (1980). Relation between particle size selection and clearance in suspension feeding ciliates. Limnol. Oceanogr. 25: 733-738

Gifford, D. J., Bohrer, R. N., Boyd, C. M. (1981). Spines on diatoms: do copepods care? Limnol. Oceanogr. 26: $1057-1061$

Gold, K. (1968). Some observations on the biology of Tintinnopsis sp. J. Protozool. 15: 193-194

Gold, K. (1969). Tintinnids: feeding experiments and lorica development. J. Protozool. 16: 507-509.

Gold, K. (1970). Cultivation of marine ciliates (Tintinnida) and heterotrophic flagellates. Helgoländer wiss. Meeresunters. 20: 264-274

Gold, K. (1971). Growth characteristics of the mass-reared tintinnid Tintinnopsis beroidea. Mar. Biol. 8: 105-108

Gold, K. (1982). Simplified procedures for maintaining Strombidium sulcatum and SEM observations on its morphology. Abstract No. 67, J. Protozool. 29: 297

Grim, J. N., Halcrow, K. R. (1979). The oligotrich ciliate Strobilidium gyrans: its freshwater environment, laboratory culture conditions, and stalking behaviour. Trans. Am. microsc. Soc. 98: 529-536

Guillard, R. R. L. (1972). Culture of phytoplankton for feeding marine invertebrates. In: Smith, W. L., Chanley, M. H., (ed.) Culture of marine invertebrate animals. Plenum Press, New York, p. 29-60

Guillard, R. R. L., Ryther, J. H. (1962). Studies on marine planktonic diatoms I. Cyclotella nana Hustedt and Detonula confervacea (Cleve). Can. J. Microbiol. 8: 229-239

Heinbokel, J. F. (1978a). Studies on the functional role of tintinnids in the Southern California Bight. I. Grazing and growth rates in laboratory cultures. Mar. Biol. 47: 177-189

Heinbokel, J. F. (1978b). Studies on the functional role of tintinnids in the Southern California Bight. II. Grazing rates of field populations. Mar. Biol. 47: 191-197

Heinbokel, J. F., Beers, J. R. (1979). Studies on the functional role of tintinnids in the Southern California Bight. III. Grazing impact of natural assemblages. Mar. Biol. 52: 23-32

Hiwatashi, K. (1974). Conjugation and genetics in free-living protozoa. In: dePuytorac, P., Grain, J., (ed.) Actualitiés Protozoologiques. 4th Congr. Internat. Protozool, Clermont, 1973. Vol 1. Université de Clermont, Clermont, p. 129-134

Huntsman, S. A., Sunda, W. G. (1980). The role of trace metals in regulating phytoplankton growth, with emphasis on $\mathrm{Fe}$, Mn and Cu. In: Morris, I. (ed.) The physiological ecology of phytoplankton. University of California Press, Berkeley, p. $285-328$

Jackson, G. A., Morgan, J. J. (1978). Trace metal-chelator interactions and phytoplankton growth in seawater media: theoretical analysis and comparison with reported observations. Limnol. Oceanogr. 23: 268-282

Johansen, P. L. (1976). A study of tintinnids and other protozoa in Eastern Canadian waters with special reference to tintinnid feeding, nitrogen excretion, and reproduction. $\mathrm{Ph}$. D. thesis, Dalhousie University, Halifax

Kahl, A. (1932). Urtiere oder protozoa. I. Wimpertiere oder ciliata (Infusoria). 3. Spirotricha. In: Dahl, F. (ed.) Die Tierwelt Deutschlands und der angrenzenden Meeresteile. Gustav Fischer Verlag, Jena, p. 487-518

Landry, M. R., Hassett, R. P. (1982). Estimating the grazing impact of marine microzooplankton. Mar. Biol. 67: 283-288

Laval-Peuto, M. (1977). Reconstruction dune lorica de forme 
Coxliella par le trophont nu de Favella ehrenbergii (Ciliata, Tintinnina). C. r. hebd. Séanc. Acad. Sci., Paris 284D: $547-550$

Lohmann, H. (1908). Untersuchungen zur Feststellung des vollständigen Gehaltes des Meeres an Plankton. Wiss. Meeresunters. (Abt. Kiel) 10: 131-370

Lewin, J., Chen, C. (1973). Changes in the concentration of soluble and particulate iron in seawater enclosed in containers. Limnol. Oceanogr. 18: 590-596

Martinez, E. A. (1983). Effects of temperature and food concentration on competitive interaction in three species of marine Ciliophora. Caribb. J. Sci. 19: 1-7

Paranjape, M. (1980). Occurrence and significance of resting cysts in a hyaline tintinnid, Helicostomella subulata (Ehre.) Jorgensen. J. exp. mar. Biol. Ecol. 48: 23-33

Rassoulzadegan, F., Gostan, J. (1976). Répartition des ciliés pélagiques dans les eaux de Villefrañche-sur-Mer. Rémarques sur la dispersion du micro-zooplancton en mer et à l'interieur des échantillons dénombrés par la methode d'Untermohl. Annls Inst. océanogr., Paris 52: 175-188

Sieburth, J. McN. (1982). Status and perspectives of marine pelagic protozoology: a synthesis of the workshop at Villefranche-sur-Mer, France, 1981. Annls Inst. océanogr., Paris 58(S) : 243-248

Smetaček, V. (1981). The annual cycle of the protozooplankton in Kiel Bight. Mar. Biol. 63: 1-11

Sorokin, Yu. I. (1981). The heterotrophic phase of plankton succession in the Sea of Japan. Mar. Biol. 41: 107-117
Sorokin, Yu. I. (1977). Microheterotrophic organisms in marine ecosystems. In: Longhurst, A. R. (ed.) Analysis of marine ecosystems. Academic Press, London, p. 293-341

Spittler, P. (1973). Feeding experiments with tintinnids. Oikos 15(S): $125-132$

Stoecker, D. K., Guillard, R. R. L., Kavee, R. M. (1981). Selective predation by Favella ehrenbergii (Tintinnina) on and among dinoflagellates. Biol. Bull. mar. biol. Lab., Woods Hole 160: 136-145

Stoecker, D. K., Davis, L. H., Provan, A. (1983). Growth of Favella sp. (Ciliata:Tintinnina) and other microzooplankters in cages incubated in situ and comparison to growth in vitro. Mar. Biol. 75: 293-302

Stoecker, D. K., Davis, L. H., Anderson, D. M. (1984). Fine scale spatial correlation between planktonic ciliates and dinoflagellates. J. Plankton Res. 6: 829-842

Strathmann, R. R. (1967). Estimating the organic carbon content of phytoplankton from cell volume of plasma volume. Limnol. Oceanogr. 12: 411-418

Throndsen, J. (1978). Preservation and storage. In: Sourinia, A. (ed.) Phytoplankton manual. UNESCO, Paris, p. 69-74

Trick, C. G., Anderson, R. J., Gillam, A., Harrison, P. J. (1983). Prorocentrin: an extracellular siderophore produced by the marine dinoflagellate Prorocentrum minimum. Science 219: 306-308

Verity, P. G. (1984). The physiology and ecology of tintinnids in Narragansett Bay, Rhode Island. Ph. D. thesis, University of Rhode Island, Kingston

This paper was submitted to the editor; it was accepted for printing on February 28, 1985 